\title{
SOCIAL RESPONSIBILITY OF FIRMS AND THE IMPACT OF BIO-ECONOMY IN INTELIGENT USE OF RENEWABLE ENERGY SOUREES
}

\author{
Mihai Andronie ${ }^{1}$, Violeta-Elena Simion ${ }^{2 *}$, Elena Gurgu ${ }^{3}$, Adrian Dijmărescu ${ }^{4}$ \\ and Irina Dijmărescu ${ }^{5}$ \\ ${ }^{1) 23)}$ Spiru Haret University, Bucharest, Romania \\ 4) University of Medicine and Pharmacy "Carol Davila" Bucharest, Romania \\ ${ }^{5)}$ Emergency Clinical Hospital for Children "Grigore Alexandrescu" \\ Bucharest, Romania
}

\begin{abstract}
Please cite this article as:
Andronie, M., Simion, V.E., Gurgu, E., Dijmărescu, A. and Dijmărescu, I., 2019. Social Responsibility of Firms and the Impact of Bio-Economy in Intelligent Use of Renewable Energy Source. Amfiteatru Economic, 21(52), pp. 520-535.
\end{abstract}

DOI: $10.24818 / \mathrm{EA} / 2019 / 52 / 520$

\section{Article History}

Received: 30 March 2019

Revised: 18 May 2019

Accepted: 18 June 2019

\begin{abstract}
Through its whole set of activities related to the invention, development, production and use of biological products and processes, bio-economy contributes significantly to the economy and to the progress of society by improving the sustainability of health, nutrition, energy efficiency, industry, environmental protection and human well-being in general. In this study, by creating an overview of the efficiency of renewable energy sources, in the context of sustainable resource management for preserving a healthy, diverse and resilient ecosystem, the research aimed to show the unused renewable energy sources at maximum potential in Romania, what are the reasons for their non-use, what are the opportunities and what are the solutions that can be adopted for the exploitation of these types of renewable energy sources in Romania. In the European Union, geothermal energy has already been well exploited and, in the future, will no longer make a significant contribution to increasing the productivity of renewable energies. Eurostat data was collected and processed using a linear regression model on the primary production of renewable energy in Romania and the rest of the European states for a period of 11 years (2005-2016); at the same time, statistical forecasts were made for the years 2017 and 2018 and was pursued to what extent social responsibility activities of companies is in line with the principles of bio-economy. In Romania, there is a very high potential for both geothermal energy that is insufficiently exploited to date and for the transformation of municipal waste into energy. It also explores the possibility of using intelligent information systems to optimize the exploitation of renewable energy sources. An important role in this effort is made by companies that, by adopting a Social Responsibility Code (CRS), can bring not only benefits, but also create a positive image with favorable consequences for all parties involved.
\end{abstract}

Keywords: social responsibility, bio-economy, natural resources, sustainability, intelligent use of resources

JEL classification: C2, D66, M30, O3, Q56

* Corresponding author, Simion Violeta-Elena - simion.violeta.elena@gmail.com 


\section{Introduction}

The crisis of resources, unemployment and inflation are, as Georgescu-Roegen (2008) said, "the most curious thing that could happen" and which surprised the economists who supported their position with arguments "such as ensuring the well-being for everybody through unrestricted and accelerated economic growth, a statement as unfounded as that people could be made immortal". This approach to economic progress, however, ignores an extremely important issue, that of natural resources. They have played the most important role in human history and are indispensable to our exosomatic way of life but are limited and degraded at a very high speed as they enter economic processes (Georgescu-Roegen, 2008). Sustainability is a key criterion, whatever the social responsibility of a person, a business, or even a community. The sustainability term was proposed by the World Commission for the Environment and Development of the United Nations (1987) and it means "ensuring development to meet the needs of present generations without compromising the ability of future generations to meet their own needs".

In this context, companies need to be analyzed and evaluated not only in terms of financial indicators but also in terms of social and environmental performance.

Legislation supports this by adopting EU Directive 34/2013 as amended by EU Directive $95 / 2014$, and, for identifying best practices and tracking progress, a series of reference codes/frameworks are developed so that firms can report their social responsibility efforts and actions adopted as transparent as possible, contributing to the transition from a consumer economy to a sustainable economy such as bio-economy.

Grigore Antipa is the author and founder of some modern concepts in the field of ecology, biosociology and bio-economy of the biosphere, which are still valid. Through his work, "L'organisation generale de la vie collective, des organismes et du mecanisme de la production dans la Biosphere" (1935), Antipa laid the foundations for bioeconomy and mentioned for the first time this term to denote an interdisciplinary science. This type of economy refers to the sustainable production and conversion of biomass into food, industrial products and energy to ensure a safe, healthy and prosperous environment for current and future generations. Bioeconomy through sustainability makes a major contribution to ensuring global food security, improving nutrition and health of the population, creating bio-products, producing biofuels, supporting agriculture, forestry, aquaculture so that they are adapted to climate change.

Now being socially responsible is not just an option but a moral and business requirement for modern corporate firms. Non-integration into this current affects the entity, their stakeholders, and the environment in which they operate. A representative study in this regard, indicating a solution to extrapolate from firm level to corporate level, shows that business groups can serve as an instrument capable of conducting corporate social responsibility actions for third parties such as be large enterprises, national or multinational corporations or even government. The advantage for business groups or SMEs is to have access to more resources, information and knowledge, already known, thus increasing their potential to carry out socially responsible actions (Săvoiu et al., 2011).

There is an increasing number of signals that our civilization is in deadlock, survival on the basis of sustainable productivity of natural systems is overtaken at this time, evolution showing that we feed our consumption by suppressing natural wealth and overcoming the regeneration capacity of the planet. In this context, corporate social responsibility must 
actively contribute through the activities, technologies and solutions proposed to the implementation of the bio-economy principles. In this study, by creating a picture of the efficiency of renewable energy sources, in the context of sustainable resource management for preserving a healthy, diverse and resilient ecosystem, we sought to see what renewable energy components are not used at maximum potential, which are the causes of non-use and which may be the opportunities for exploitation of renewable energy sources in Romania.

\section{References on the application of the Social Responsibility Code}

\subsection{References on CSR application at international level}

The concept of corporate social responsibility is a means for companies to voluntarily integrate social and environmental responsibility into their business plan and relationship with stakeholders in society. Corporate social responsibility does not only mean compliance with rules, but also involves investment in human and environmental capital, as well as a civic and social involvement of companies that will bring benefits to the whole community (Dinu, 2001). The international situation regarding corporate social responsibility shows clear differences between how it is addressed at the level of small and medium-sized firms compared to multinational corporations. These aspects reflect the legislative, cultural, and organizational differences of countries that give some direction in addressing CSR strategies. A study by Pérez and Márquez (2015) shows that CSR can help to promote environmental sustainability by improving the behavior of a company, although in Latin America this is a tool mostly used by Spanish companies (Spanish MNEs) to adapt effectively to the socio-economic context of the region and less used to ensure environmental sustainability (Pérez and Márquez, 2015). An analysis of CSR in multinational organizations in Japan and Australia shows some differences - Japan's organizations focus on economic, social and environmental considerations while Australian organizations focus on environmental and partly social issues. These differences do not offer many possibilities for developing a universally accepted sustainability framework with the same measurement parameters that are to be fully respected (Sawhny, 2008).

All stakeholders - industry representatives, associations, firms, corporations, scientists, farmers, foresters, fishermen etc., together with the community where they are integrated must develop initiatives and programs to support social responsibility, provide advice on implementing strategies and solutions for common European and international actions and measures. Progress on social responsibility should be monitored and evaluated for an optimal and consistent management of the wide range of data aspects provided by firms for the purpose of evaluating the results.

\subsection{Social Responsibility activity in Romania}

A survey conducted over 2007-2010 on a representative sample of SMEs in Romania showed that their concerns were mainly to prevent occupational health and safety risks and were less involved in the active life of the community in assessing its perception of the social impact of the organization and the use of performance indicators related to this impact (Olaru, Stoleriu and Şandru, 2011). Băleanu, Chelcea and Stancu (2011), analyzing the corporate social 
responsibility of the top 100 companies in Romania based on the analysis of their web sites, concluded that "the mere presence of CSR at the level of corporate corporate communication does not attest a real responsibility of the company at the social level or a vision of integrating CSR into the company's overall strategy", and the study's conclusions highlighted: "the wilingness of companies to comply with the laws in force and to treat fairly and equitably with relevant stakeholders; addressing a predominantly economic view that places CSR as competitive advantage on the market; representing the community as the main benneficiary of the company's interests and its CSR related activity and ignoring those interest holders that have a lesser influence on the company's economic activity; poor strategic integration of corporate social responsibility; poor effective coordination with the rest of the actors in the social spectrum; the predilection for less costly SCR methods of action at an organizational level". From here, however, to visions and strategies of responsible engagement in the needs of the community in which the company and its employees work, it is a longer journey. The existence of only a code of good business practice, a code of good employee behavior, and a company's social responsibility strategy, beyond a legal framework, results in only small, unsustainable results. SMEs, through flexible and open to change, there a few that focus on innovation based on risk factors and methods of reducing them (Țoniş-Bucea-Manea, 2015).

The third edition of the "CSR Index 2018" launched by The Azores Sustainability \& CSR Services shows that the 2018 results indicate a slightly increased interest over previous years, but around $40 \%$ of companies have not published any information on the social or environmental impact for 2016. The only visible information was "invest in community" and "economic impact", which is very little. On the other hand, there is an improvement in the communication and transparency of the social responsibility acts that the companies carry out within the community, increasing the number of projects regarding the Romanian traditions and culture. The study also showed that six companies have exceeded the 90-point threshold, and information on sustainable development in Romanian companies is beginning to contain more and more measurement parameters and more sustainability objectives.

\subsection{What are the solutions?}

Innovation must not only be a technical breakthrough or an accumulation of new knowledge but can also be considered innovation when it leads to resource saving. We can not maximize present welfare, undermining the future (Georgescu-Roegen, 2008). Solar energy, for example, is a viable resource and can be exploited by solar collectors, but this is only a possible, not necessarily a sustainable solution. Georgescu-Roegen (1978) said that "possible solar solutions are parasites of current technology and, like all parasites, will not survive the disappearance of their host". Any alternative energy solution that we evaluate is closely related to the primary source that generated it and is conditioned by "its sufficiency to reproduce the material substance of the process that produced it" (Georgescu-Roegen, 1978). Given any conception of the economic circuit, the relationships between the economic process and the environment, we must take into account that "the feasibility of all matrix solutions does not guarantee the viability of their global system. A technology represented by a matrix of feasible solutions is viable if and only if it can reproduce the global process it represents as long as this system can be fed with the resources specific to the particular environment it needs" (Gerogescu-Roegen, 2008). Brown (2011), quoting Achim Steiner (Executive Director of UNEP), shows that regarding climate change and the pressure to move to a green economy, the most important political 
tool in carbon neutralization is, on the one hand, the restructuring of taxes and subsidies, which may mean lowering taxes on income and increasing taxes on environmentally damaging activities and, on the other hand, redirecting subsidies away from environmental damaging activities such as burning fossil fuels, emptying aquifers, deforesting and excessive fishing (Brown, 2011).

Currently, a number of states, both in Europe and the United States, have adopted schemes for systematically redirecting income taxes to environmental actions. The coal industry is considered one of the most "aggressive" in terms of environmental impact. Measures such as taxing coal so that its price includes the costs of mining-related healthcare, air pollution, acid rain and climate damage, or the calculation of gasoline prices to include the costs of treating diseases caused by exhaust gases, for example, can stimulate investment in renewable energy sources. Romania is in the process of shutting down its coal mines, but this process has had negative repercussions on the communities in the region and has created a major risk in terms of environmental management without providing viable alternatives. At European level, tax re-allocation is currently being applied in more and more countries: in Germany, for example, taxes are redirected from work to energy, contributing to the annual reduction of $\mathrm{CO}_{2}$ emissions but also to the creation of new jobs in the renewable energy sector; similar activities of redirecting taxes to transport, for example, have been applied in countries such as France, Italy, Norway, Spain and the United Kingdom; garbage dumps that encourage waste and discourage recycling are increasingly being taxed (Brown, 2011). A second approach concerns the elimination of subsidies from industries with a negative impact on the environment, which means "greater energy efficiency, reducing carbon emissions and reducing environmental damage, that is a triple advantage - a win-win-win situation" (Brown, 2011).

\section{Research methodology}

In this research, we collected data from Eurostat (2019) to create a snapshot/panorama of the efficiency of green energy production. The data collected are time series from 2005 to 2018 on renewable energy and its components: hydropower, wind energy, solar photovoltaic energy, solid biofuels (excluding coal), biogas, municipal (renewable) waste, biodiesel and geothermal energy. Eurostat presents data from all 28 European countries and an average for Europe from 2005 to 2016. The data from 2017 and 2018 were obtained on the basis of a statistical forecast. For the design of our study, we chose data on primary production on renewable energy in Romania and the EU average. Then we collected data for each major component of renewable energy production. The data collected from the eight different EU tables (28 countries) were condensed in table no. 1. The same methodology was applied to Romania, as shown in table no. 2. 
Table no. 1: Primary production on renewable energies and its components for the $\mathrm{EU}$ ( 28 countries)

\begin{tabular}{|c|c|c|c|c|c|c|c|c|c|}
\hline 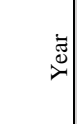 & 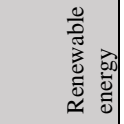 & 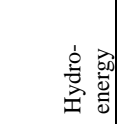 & 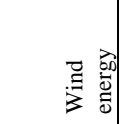 & 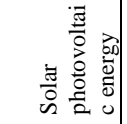 & 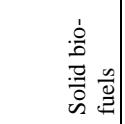 & 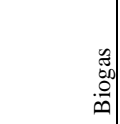 & 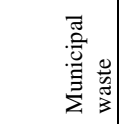 & 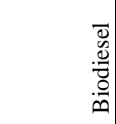 & 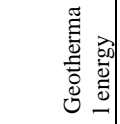 \\
\hline 2005 & 120264.1 & 26940.2 & 6057.9 & 125.6 & 67757.0 & 4058.3 & 5995.8 & 2501.9 & 5309.2 \\
\hline 2006 & 126524.8 & 27171.8 & 7078.5 & 214.5 & 69422.4 & 4460.9 & 6503.7 & 3643.7 & 5486.9 \\
\hline 2007 & 136265.9 & 27036.9 & 8976.0 & 324.5 & 72888.6 & 5848.6 & 7425.2 & 5118.6 & 5623.4 \\
\hline 2008 & 145647.9 & 28570.5 & 10279.1 & 639.5 & 76794.6 & 6677.5 & 7408.6 & 6378.1 & 5619.2 \\
\hline 2009 & 153353.4 & 28872.7 & 11441.0 & 1205.6 & 79507.1 & 7493.8 & 7653.2 & 7824.5 & 5473.1 \\
\hline 2010 & 169160.9 & 32410.7 & 12845.1 & 1934.9 & 86238.2 & 8705.7 & 8110.9 & 8878.8 & 5517.4 \\
\hline 2011 & 165795.3 & 26845.7 & 15475.9 & 3896.6 & 82270.8 & 10611.7 & 8392.8 & 8388.2 & 5760.9 \\
\hline 2012 & 182260.8 & 28876.4 & 17715.4 & 5793.6 & 88723.7 & 12353.8 & 8670.8 & 8905.1 & 5683.8 \\
\hline 2013 & 195040.3 & 31950 & 20356.8 & 6957.8 & 90395.3 & 14102.3 & 8987.3 & 9700.7 & 5901.4 \\
\hline 2014 & 197880.1 & 32244.5 & 21762.9 & 7939.3 & 87229.9 & 15119.0 & 9302.7 & 11376.4 & 6158.0 \\
\hline 2015 & 205781.5 & 29327.9 & 25956.7 & 8796.7 & 91833.9 & 15886.8 & 9648.5 & 10983.5 & 6461.8 \\
\hline 2016 & 210708.0 & 30105.0 & 26044.2 & 9047.4 & 94124.6 & 16600.1 & 10001.0 & 10761.6 & 6659.5 \\
\hline 2017 & 223522.3 & 31514.54 & 27857.55 & 10179.07 & 97806.92 & 18325.69 & 10373.48 & 12873.66 & 6478.555 \\
\hline 2018 & 232236.6 & 31808.87 & 30065.25 & 11468.01 & 99909.83 & 19753.35 & 10644.02 & 13401.90 & 6598.148 \\
\hline
\end{tabular}

Table no. 2: Primary production of renewable energies and its components for Romania

\begin{tabular}{|c|c|c|c|c|c|c|c|c|c|}
\hline$\underset{\nabla}{\vec{J}}$ & $\begin{array}{ll}\overline{0} & \\
\text { है } & 00 \\
0 & 0 \\
0 & 0 \\
0 & 0 \\
\simeq & 0\end{array}$ & 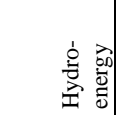 & 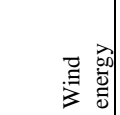 & 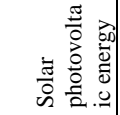 & 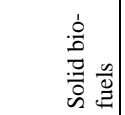 & $\begin{array}{l}\tilde{g} \\
.00 \\
.0 \\
0\end{array}$ & 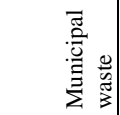 & 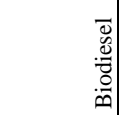 & 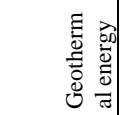 \\
\hline 2005 & 4984.2 & 1737.5 & 0 & 0 & 3228.9 & 0 & 0 & 0 & 17.9 \\
\hline 2006 & 4831.0 & 1578.3 & 0 & 0 & 3234.9 & 0 & 0 & 0 & 17.8 \\
\hline 2007 & 4717.7 & 1372.8 & 0.3 & 0 & 3304.1 & 1.3 & 0 & 19.6 & 19.6 \\
\hline 2008 & 5336.1 & 1478.5 & 0.4 & 0 & 3749.7 & 0.6 & 0 & 81.6 & 25.2 \\
\hline 2009 & 5274.6 & 1335.7 & 0.8 & 0 & 3838.4 & 1.1 & 0 & 72.3 & 23.6 \\
\hline 2010 & 5708.4 & 1709.6 & 26.3 & 0 & 3900.0 & 3.1 & 0 & 10.8 & 23 \\
\hline 2011 & 5027.5 & 1266.4 & 119.3 & 0.1 & 3475.9 & 13.1 & 0 & 94.1 & 23.8 \\
\hline 2012 & 5242.2 & 1037.5 & 227 & 0.7 & 3795.1 & 27.3 & 0 & 88.7 & 23.3 \\
\hline 2013 & 5560.8 & 1286.1 & 388.7 & 36.1 & 3656.7 & 19.6 & 0.2 & 120.8 & 26 \\
\hline 2014 & 6089.6 & 1617.0 & 533.2 & 139 & 3645.7 & 19.3 & 1.9 & 96.9 & 28.3 \\
\hline 2015 & 5935.0 & 1430.2 & 607.3 & 170.4 & 3521.0 & 18.3 & 1.1 & 131.8 & 29.1 \\
\hline 2016 & 6095.6 & 1550.1 & 566.6 & 156.5 & 3579.4 & 17.7 & 1.7 & 150.6 & 36 \\
\hline 2017 & 6130.0 & 1359.414 & 618.1364 & 142.1455 & 3754.815 & 25.32121 & 1.383333 & 156.6394 & 32.77576 \\
\hline 2018 & 6285.011 & 1390.217 & 711.9136 & 166.6727 & 3739.984 & 28.24343 & 1.621717 & 169.4343 & 34.15253 \\
\hline
\end{tabular}

Eurostat presents renewable energy data until 2016. In order to have a more precise perspective on renewable energies, we forecast data for 2017 and 2018 for the EU and Romania average. Drawing from the data collected, our research aims to find out what are the untapped renewable energy components at maximum potential and why they are not used. 
The research is based on a linear regression model applied to primary productions of renewable energy in the EU as well as in Romania. The models make predictions for the near future and reveal critical points on renewable energies and elements that have the potential to increase primary production of renewable energy. The comparison between the EU and Romania reveals opportunities and weaknesses in the implementation of environmental policy in Romania.

\section{Results and discussion}

We are currently witnessing two energy revolutions: the first concerns new energy-efficient technologies such as switching from incandescent bulbs, for example, to light-emitting diodes (LEDs), or from internal combustion engines to hybrid and electric cars with much lower fuel consumption; the second revolution marks the shift from an oil, gas or coal economy to a wind, solar or geothermal economy (Brown, 2011).

\subsection{Primary production of renewable energy in the EU}

The first equation of the regression model is presented below:

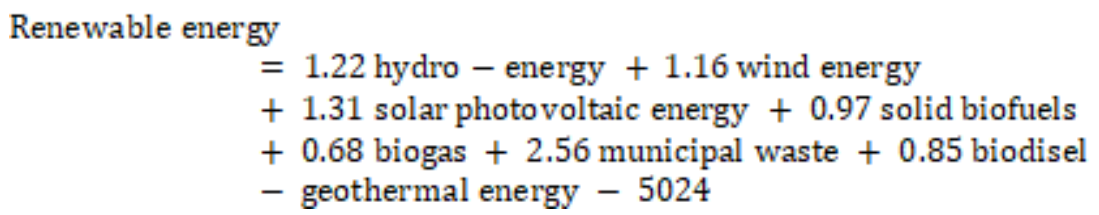

The $\mathrm{R}^{2}$ value of this model is 0.99 , indicating that $99 \%$ of the variance of the renewable energy variable is determined by the variation of causal variables (hydropower, wind energy, solar photovoltaics, solid biofuels, biogas, municipal waste, biodiesel, geothermal energy) and $1 \%$ of this influence cannot be explained by the model. As $\mathrm{R}^{2}$ has values closer to 1 , the regression model better aproximates the data in the sample. In this case, the value of 0.99 shows that the model is very good, but there are other factors that could be included in the model (table no. 3).

Also, the adjusted value of $\mathrm{R}^{2}(0.99)$ is close to $\mathrm{R} 2$, which demonstrates that the influence of the independent variables (hydropower, wind energy, solar photovoltaic, solid biofuels, biogas, municipal waste) are significant to explain the variance of the dependent variable sources. The F test for each generated variable validates the model and contributes to predictive regression power. The significance threshold of variables (Prob) should be less than or equal to 0.05 . In our case, test $F$ is significant, $F$ value (Significance F: $1.42 \mathrm{E}-16$ ) is less than 0.01 .

The predicted coefficients of the independent variables can also be found below. They show which variable can increase or reduce the productivity of renewable energies in the coming years. We can see that in the EU the geothermal energy has already been exploited very well and will in the future not bring an increase in the productivity of renewable energies. Also, we can see that some renewable energy sources, such as solid biofuels, biogas and biodiesel, will have less influence on the productivity of renewable energies in the near future. These resources were almost exhausted. 
Consideration should be given to the estimated coefficients of the regression equation. (Table no. 3) For most variables in table no. 3 the significance threshold (value P) is less than or equal to 0.05 , which means that with a high probability and a low standard error the coefficients are well explained. Exceptions are the intercept (free term), biogas and geothermal energy, since the value $\mathrm{p}>0.05$.

In conclusion, the alternative hypothesis is accepted. We can say that all forms of renewable energy have been exploited very well in the EU.

Table no. 3: Results of ANOVA regression and test

\begin{tabular}{|c|c|c|c|c|c|c|}
\hline \multicolumn{7}{|l|}{ SUMMARY OUTPUT } \\
\hline \multicolumn{2}{|l|}{ Regression Statistics } & & & & & \\
\hline Multiple R & 0.999988 & & & & & \\
\hline R Square & 0.999976 & & & & & \\
\hline Adjusted R Square & 0.999938 & & & & & \\
\hline Standard Error & 285.7809 & & & & & \\
\hline Observations & 14 & & & & & \\
\hline \multirow{2}{*}{\multicolumn{7}{|c|}{ ANOVA test }} \\
\hline & & & & & & \\
\hline & $d f$ & SS & $M S$ & $F$ & Significance $F$ & \\
\hline Regression & 8 & $1.71 \mathrm{E}+10$ & $2.14 \mathrm{E}+09$ & 26188.49721 & $4.02 \mathrm{E}-11$ & \\
\hline Residual & 5 & 408353.5 & 81670.7 & & & \\
\hline \multirow[t]{3}{*}{ Total } & 13 & $1.71 \mathrm{E}+10$ & & & & \\
\hline & & & & & & \\
\hline & Coefficients & Standard Error & $t$ Stat & $P$-value & Lower 95\% & Upper 95\% \\
\hline Intercept & -5024.55 & 8436.065 & -0.5956 & 0.577373586 & -26710.1 & 16661.04 \\
\hline Hydro power & 1.22502 & 0.099966 & 12.25434 & $6.4026 \mathrm{E}-05$ & 0.968049 & 1.481992 \\
\hline Wind power & 1.163143 & 0.288107 & 4.037185 & 0.009950332 & 0.422539 & 1.903746 \\
\hline Solar photovoltaic & 1.311788 & 0.516698 & 2.538792 & 0.05197018 & -0.01643 & 2.640002 \\
\hline Solid biofuels (excluding charcoal) & 0.971785 & 0.084239 & 11.53605 & $8.58367 \mathrm{E}-05$ & 0.755242 & 1.188328 \\
\hline Biogas & 0.687519 & 0.557632 & 1.232926 & 0.272405522 & -0.74592 & 2.120958 \\
\hline Municipal waste (renewable) & 2.562726 & 1.009556 & 2.538469 & 0.051990685 & -0.03242 & 5.157872 \\
\hline Biodiesels & 0.845653 & 0.263652 & 3.207457 & 0.023796187 & 0.167914 & 1.523393 \\
\hline Geothermal Energy & -0.14604 & 1.720587 & -0.08488 & 0.935650963 & -4.56895 & 4.276867 \\
\hline
\end{tabular}

\subsection{Primary production of renewable energy in Romania}

The equation of regression of the second model is outlined below:

Renewable energies

$$
\begin{aligned}
& =1.02 \text { hydroelectric power }+0.94 \text { wind energy } \\
& +1.31 \text { solar photovoltaic }+0.99 \text { solid biofuels }+3.94 \text { biogas } \\
& -35.93 \text { municipal waste }+0.64 \text { biodisel } \\
& +7.14 \text { geothermal energy }-113
\end{aligned}
$$

Interpretation of the model for Romania is very similar, because adjusted $\mathrm{R}^{2}$ and $\mathrm{R}^{2}$ have the same value as in the previous model, 0.99 . The $\mathrm{F}$ test for each generated variable validates the model and contributes to predictive regression power. The significance threshold of variables (Prob) should be less than or equal to 0.05. In this case, test $\mathrm{F}$ is significant, F (Significance F: 9.29E-10) is less than 0.01.

In table no. 4 the predicted coefficients of the independent variables can be found. In Romania, the situation is similar for most indicators. There is a very high potential for geothermal energy that has not been exploited well to date. Also, Romania needs to increase interest in transforming municipal waste into energy. The municipal waste 
recycling rate in Romania in 2014 was $16 \%$, compared with the EU, where the average was $44 \%$, or the North European countries, where this value increases to 64\% (Vela, 2017).

In the Circular Economy Package, the European Commission has put forward a proposal to be implemented in competitive companies, such as the recycling of $65 \%$ of municipal waste by 2030 or the recycling of $75 \%$ of packaging waste by 2030 (European Commission, 2019). Romania is behind in terms of recycling, with high waste disposal rates and not adopting management plans and programs to prevent waste generation. These were discontinued in 2013. No policies or solutions for waste management have been implemented since 2013 (Vela, 2017). This hypothesis is demonstrated in the negative coefficient $(-35.93)$ of municipal waste in this model.

Consideration should be given to the estimated coefficients of the regression equation. (Table no. 4) For most variables, the significance threshold ( $\mathrm{P}$ value) is less than or equal to 0.05 , which means that with a high probability and a low standard error, the coefficients are well appreciated. The exception is the intercept because the value $p>0.05$. With a probability of $95 \%$ and a standard error of 53.1, the intercept can be found in the range $[-249,806,23,23073]$.

Table no. 4: Results of ANOVA regression and test and coefficients of the regression model

\begin{tabular}{|c|c|c|c|c|c|c|}
\hline \multicolumn{7}{|c|}{ SUMMARY OUTPUT } \\
\hline \multicolumn{7}{|c|}{ Regression Statistics } \\
\hline Multiple R & 0.999958 & & & & & \\
\hline R Square & 0.999916 & & & & & \\
\hline Adjusted R Square & 0.999782 & & & & & \\
\hline Standard Error & 7.814606 & & & & & \\
\hline Observations & 14 & & & & & \\
\hline \\
\hline ANOVA test & $d f$ & $S S$ & $M S$ & $F$ & Significance F & \\
\hline Regression & 8 & 3641160 & 455145 & 7453.077 & $9.29 \mathrm{E}-10$ & \\
\hline Residual & 5 & 305.3403 & 61.06807 & & & \\
\hline \multirow[t]{2}{*}{ Total } & 13 & 3641465 & & & & \\
\hline & Coefficients & $\begin{array}{l}\text { Standard } \\
\text { Error }\end{array}$ & t Stat & $P$-value & Lower $95 \%$ & $\begin{array}{c}\text { Upper } \\
95 \%\end{array}$ \\
\hline Intercept & -113.288 & 53.10803 & -2.13316 & 0.086059 & -249.806 & 23.23073 \\
\hline Hydro power & 1.024098 & 0.032072 & 31.93156 & $5.66 \mathrm{E}-07$ & 0.941655 & 1.106541 \\
\hline Wind power & 0.938691 & 0.0864 & 10.86447 & 0.000115 & 0.716593 & 1.16079 \\
\hline Solar photovoltaic & 1.206548 & 0.237422 & 5.081882 & 0.003828 & 0.596237 & 1.81686 \\
\hline $\begin{array}{l}\text { Solid biofuels } \\
\text { (excluding charcoal) }\end{array}$ & 0.989209 & 0.014561 & 67.93501 & $1.31 \mathrm{E}-08$ & 0.951778 & 1.026639 \\
\hline Biogas & 3.942816 & 1.069455 & 3.686754 & 0.014193 & 1.193695 & 6.691936 \\
\hline $\begin{array}{l}\text { Municipal waste } \\
\text { (renewable) }\end{array}$ & -35.9321 & 11.62392 & -3.09122 & 0.027122 & -65.8124 & -6.05189 \\
\hline Biodiesels & 0.637713 & 0.218532 & 2.918165 & 0.033084 & 0.075958 & 1.199467 \\
\hline Geothermal Energy & 7.143378 & 2.039557 & 3.502416 & 0.01724 & 1.90053 & 12.38623 \\
\hline
\end{tabular}

Romania strives to improve its corporate responsibility performance. Although some steps have been taken and the Romanian legislation accurately reflects the environmental requirements agreed at EU level, it still has high problems with the high level of pollution has higher greenhouse gas emissions per unit of gross domestic product than the EU 
average (Ivaşcu, 2017). This high pollution is due to the energy tax rate that is lower than the EU average; it seems that Romania does not have an intensive economy to improve energy efficiency; waste management and treatment of used water (the model below supports this hypothesis). It is recommended to access EU funds or obtain extra revenues from environmental taxes to solve these problems by strengthening the management of the environmental administrative mechanism.

In Romania, social responsibility has shown results: "467 companies per million inhabitants have implemented an ISO 14001 certification in 2015" (Ivaşcu, 2017), showing an intense concern for environmental protection. But "there is a lack of trust in political and administrative structures, leading to a low responsibility for decisions and policies” (Vela, 2017).

To achieve profit, Romanian companies reduce production costs as much as they can but are still reluctant to use recycled resources as components of production materials. There are companies that support waste management policies by selectively collecting them, but Romania cannot reach the European 2020 targets in this area. This requires a change in public recycling behavior (Ferronato, 2019). In terms of water quality and management, these can be improved in Romania by using monitoring networks and methods of water composition assessment (Vela, 2017). All farmers should adhere to mandatory measures set by specialists to reduce agricultural pressures.

In Romania, there is a low interaction between the various actors working in the industrial field, this field being also characterized by the low visibility of social entrepreneurship. Economic agents have their own preconceptions about the principles of the circular economy, not paying attention to the implementation of these principles by other agents in order to form an ecosystem together. It is aimed to "raise awareness among employees and stakeholders about corporate responsibility, motivating them to integrate and support the value chain" (Staicu, 2018). This result is deduced from operational loopholes in the supply chain of most Romanian industries, lack of trust in Romanian companies, collaboration mechanisms, rarity of good practices and network governance models of companies. These can lead to a bottom to top clustering approach to enable cooperation in the Green Supply Chain (GSCC).

If a new style of governance were adopted to continue cooperation, networking and improving value chain specialization as a result of regional policy motivation, if there were networks of companies leading up to the bottom to top clustering and focus on innovative management and learning processes, the transition of Romanian producers to EU requirements could be facilitated. But in the absence of concrete measures of this kind, the Romanian producers are in danger of failing to cope with the transition difficulties imposed by the EU legislation, and finally, the Romanian companies can be excluded from the European market by competitive pressures (Botezat, 2018). It seems that there are specialists in this area because Romania has developed innovative approaches with other countries, such as the "Green Laboratory of Recycling 2012 initiative that received the Gold Medal for Excellence in the SME category as part of the European Corporate Social Responsibility Award (CSR)". Romania has several opportunities with the EU to implement the principles of a circular economy that support sustainability. Romania needs to hire specialists in the circular economy in public sectors, allocate more funds to green businesses and increase collaborative consumption. Companies known as green are more credible, representing a guarantee of the quality of the products they offer. They increase 
consumer awareness of environmental issues and possible solutions through the existence of the "enviro" label (Epure and Bucea-Manea-Țoniș, 2017).

Collaborative consumption and sharing of a new business model can be achieved by enabling technology platforms that facilitate redistribution markets by: the reallocation of the items or services in which demand corresponds to the offer; rental of products which are not their own etc. (Pistol, Bucea-Manea-Țoniș and Bucea-Manea-Țoniș, 2017).

\subsection{Criteria and initiatives in the social responsibility of a firm}

Measuring corporate social responsibility is difficult, there are many different criteria that cannot be met at the same time by all companies. Equally, companies can get both a good rating for some criteria and an inappropriate evaluation for others, the measurement systems used, and the different concepts of CSR not having a systematic basis. There are several indicators used to measure corporate social responsibility such as: FTSE (Financial Times Stock Exchange) which measures the power of environmental, social and governance practices based on clearly defined principles with a defined scope; the eligibility criteria for companies to be included in the FTSE4Good Index series take into account concepts, strategies and actions for environmental sustainability, the development of positive relationships with stakeholders and human rights support; DJSI (Dow Jones Sustainability Indices) which is based on criteria for assessing the opportunities and risks arising from the economic, environmental and social activity of the companies included in DJSI STOXX; the assessment is based on an online questionnaire and follows indicators such as sustainability reports, environmental reports, health and safety reports, annual financial reports, special reports such as intellectual capital management, corporate governance, $\mathrm{R} \& \mathrm{D}$, employee relations, any other sources of company information such as brochures, website, etc.; Business Ethics 100 to which data highlight companies that get "strong points" (for example, for profit sharing, retirement benefits, employee involvement or pollution prevention, recycling etc.) and are concerned for social responsibility - trade union relations, labor fluctuations, emissions, climate change and regulatory issues (Hopkins, 2005); corporate responsibility can also be seen as a sum of responsible employee behaviors; the company must ensure the well-being and develop ecological behaviors of employees while increasing trust and organizational identification ( $\mathrm{Su}, 2019)$; Garcia-Martinez (2019) said that "environmental and corporate governance dimensions are the most important elements in measuring performance".

A corporate social responsibility code should address the 5 principles of bio-economy (figure no. 1).

With regard to sustainable resource management, advanced computer systems have been successfully used in some countries to optimize the production of renewable energy. For example, a study on the use of biomass as a source of renewable energy has demonstrated the usefulness of information systems for the management of biomass sources, distributed within the territory, using geographic information systems (GIS) (Morato, Vaezi and Kumar, 2019 ). Similar systems have been used to manage biogas power generation in Brazil (Freitas et al., 2019). There are also situations where computer systems have been used to determine the location of new wind farms. For example, a multicriterial data analysis based on geographic information systems (GIS) was the basis for choosing the optimal position for a wind farm in Greece (Bili and Vagiona, 2018). 


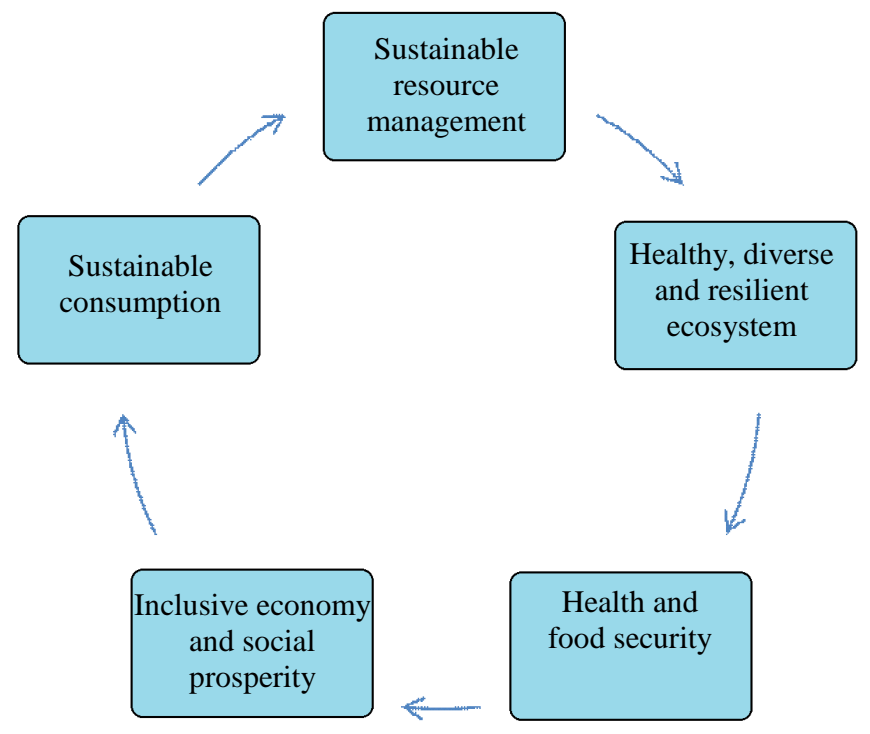

Figure no. 1: Social Responsibility Initiatives in accordance with the principles of bioeconomy

A highly debated issue at global level is the management of electrical and electronic equipment waste, which relied heavily on their imports and exports, without taking into account the socio-ecological damage caused in the countries that are mainly the recipients of this waste. Worldwide, the main solution found was the involvement of corporate social responsibility by companies acting in the electric and electronic areas. They could use these wastes to reduce external costs, helping to reduce socioeconomic damage (Marins, 2016). To preserve a healthy, diverse and resilient ecosystem, corporate social responsibility codes must provide for and initiate actions to reduce air pollution and $\mathrm{CO}_{2}$ emissions in the value chain, contributeing to the restoration, maintenance and improvement of soil and water biodiversity by useing appropriate recycling processes.

A study conducted in Romania indicates that climate change has a negative effect on the quantity and quality of crops, due to high temperatures, droughts and the seriousness of floods in gardens, orchards and fields. Respondents argue that businesses and industry are responsible for tackling the effects of climate change (Surugiu, 2018).

Inclusive economy, circular economy and social prosperity support an inclusive development (high employment) to ensure social and territorial cohesion, leading to smart growth in the field of bioeconomy by developing viable and sustainable businesses based on knowledge and innovation, providing rural and urban communities with sustainable environmental, social and economic opportunities, while encouraging partnerships (at local, regional, national and global level) where resources are harnessed more effectively.

Last but not least, a sustainable consumption is needed that encourages the use of organic products. It is necessary to rise awareness among young people, from the kindergarten to university, regarding sustainable practices and to provide an infrastructure that facilitates 
the recovery, recycling and reuse of food. The circular economy must be based on education in terms of respecting the principles of safety and the sustainable environment.

There are studies that show that CSR is driven by factors like gender (more likely, women are involved in environmental protection), personal values (people with a strong philanthropic orientation are more involved), religion (religious people are more active in protecting the environment), political ideology or the field of study (people with humanistic and social training are more enthusiastic to act voluntarily in accordance with the principles of the circular economy) (Galvão, 2019). The social responsibility of companies is now limited in scale due to the limited access of the public to the necessary information the development of creative industries and the lack of funding in this area (Sasongko, 2018). Other two elements that have a positive impact on environmental protection are corporate ethics and innovation (Lončar, 2019). Environment strategies bring a plus of image and increase customer loyalty (Heesup, Jongsik and Wansoo, 2019). Company leaders have understood that an important component of their reputation is due to the corporate name being associated with corporate social responsibility in environmental policies (LloydSmith, 2019). Sustainable development could be achieved by innovative SMEs, with investments in technologies that reduce the impact of the environmental footprint or regenerate natural resources (Bucea-Manea-Țoniş, 2015).

Moreover, Kim (2019) believes that those "controversial companies with negative reputations can restore and improve their image by engaging in marketing initiatives" related to the causes that have contributed to the image's impact (Kim, 2014).

\section{Conclusions}

The present study highlights the fact that the measurement of corporate social responsibility is difficult, with many different criteria that cannot be met by all companies at the same time - they can obtain both a good evaluation for some criteria and an inappropriate assessment for others, depending on the measurement systems used as the different concepts of CSR lack a systematic basis.

Our research showed that in the EU geothermal energy has already been exploited very well and in the future will not bring an increase in the productivity of renewable energies. We also see that some renewable energy sources, such as solid biofuels, biogas and biodiesel, will have less influence on the increase in renewable energy production in the near future, with limited resources available. However, in Romania, there is a very high potential for geothermal energy, which has not been exploited well to date, and at the same time interest has to be increased for transforming municipal waste into energy.

In Romania, there is a low interaction between the different actors working in the industrial field. This area is also characterized by a low visibility of what social entrepreneurship is, both at industry level and in the case of companies.

In our opinion, a structuring of corporate social responsibility strategies with a role to play in building sustainable businesses, depending on the level at which they act, may be the following: social and societal strategies, environmental and environmental strategies, responsible distribution and supply strategies, corporate image building strategies, competitive advantage strategies and value-adding strategies. Based on the organization's attitude to sustainability values and their degree of implementation, strategies can be: passive (defensive) 
strategies, reactive strategies and proactive strategies. The careful selection of these corporate social responsibility strategies could ensure business sustainability by gaining benefits for the organization (improving the image and reputation of the organization, increasing operational efficiency, increasing sales and customer loyalty, gaining competitive advantage, providing benefits for shareholders, increasing financial performance), employee benefits (increasing motivation, improving team unity, reducing internal conflicts, eliminating unethical practices, developing social solidarity), benefits for society (promoting social inclusion, improving cooperation with nongovernmental organizations, state institutions, customers, suppliers, competitors) and benefits to the environment (reducing the impact of economic activity on air, water, soil, exhausting natural resources, reducing consumption energy, promoting recycling and reuse of materials).

The model described and tested, although it is an incipient, pioneering investigation, opens opportunities for companies to take social responsibility actions for sustainable development. In order to achieve this goal, a company has to find the means to act, innovate and consume to maintain the best possible relationship with all stakeholder categories. The goal of society is to survive, to thrive and to be a sustainable system. In doing so, all individuals must watch to meet their current needs, but without neglecting the limited possibilities of the planet to support these needs, and without neglecting future generations and their needs. Moreover, the purpose of the environment is to be a sustainable ecological system, and this can only be achieved by stopping its destruction. Thus, the sustainable goals of the company, society and the environment are practically intertwined. Companies are powerful actors in the whole process, and their power now tends to reflect on this connection as well.

\section{References}

Antipa, G., 1933. Extrait La Biosociologie et la Bioéconomie de la Mer Noire. Bulletin de la Section Scientifique, XV(9-10).

Băleanu, T.E., Chelcea, L. and Stancu, A., 2011. The social responsibility of the top 100 Romanian companies. An analysis of corporate websites. Amfiteatru Economic, 13(29), pp.235-248.

Bili, A. and Vagiona, D.G., 2018. Use of Multicriteria Analysis and GIS for Selecting Sites for Onshore Wind Farms:The Case of Andros Island (Greece). European Journal of Environmental Sciences, [e-journal] 8(1), pp.5-13. doi: 10.14712/23361964.2018.2

Botezat, E.A., Dodescu, A.O., Văduva, S. and Fotea, S.L., 2018. An Exploration of Circular Economy Practices and Performance Among Romanian Producers. Sustainability, [e-journal] 10(9). doi: 10.3390/su10093191.

Brown, L., 2011. Planul B 4.0. Mobilizarea generală pentru salvarea civilizației. București:Expert.

Dinu, V., 2011. Corporate social responsibility - opportunity for reconciliation between economical interests and social and environmental interests. Amfiteatru Economic, 13(29), pp.6-7.

Epure, M. and Bucea-Manea-Țoniş, R., 2017. Branding and Leadership in the context of Circular Economy. Procedia of Economics and Business Administration, pp.163-172.

European Commission, 2019. Environment. [online] Available at: <http://ec.europa.eu/ environment/circular-economy/index_en.htm> [Accessed 2 February 2019]. 
Eurostat, 2019. Eurostat. Database. [online] Available at: <https://ec.europa.eu/eurostat/ data/database> [Accessed 2 February 2019].

Ferronato, N., Rada E.C., Portillo M.A.G, Cioca, L.I.C., Ragazzi, M. and Torretta, V., 2019. Introduction of the circular economy within developing regions: A comparative analysis of advantages and opportunities for waste valorization. Journal of environmental management, 230, pp.366-378.

Freitas, F.F., De Souza, S.S., Ferreira, L.R.A., Otto, R.B., Alessio, F.J., De Souza, S.N.M., Venturini, O.J. and Ando, O.H., 2019. The Brazilian market of distributed biogas generation: Overview, technological development and case study. Renewable \& Sustainable Eergy Review, [e-journal] 101, pp.146-157. doi: 10.1016/ j.rser.2018.11.007.

Galvão, A., Mendes, L., Marques, C. and Mascarenhas, C., 2019. Factors influencing students' corporate social responsibility orientation in higher education. Journal of Cleaner Production, 215, pp.290-304.

Garcia-Martinez, G., Guijarro, F. and Poyatos, J.A., 2019. Measuring the social responsibility of European companies: a goal programming approach. International transactions in operational research, 26(3), pp.1074-1095.

Georgescu-Roegen, N., 1978. Technological Assessment: The case of direct use of solar energy. Atlantic Economic Jurnal, 6, pp.15-21.

Georgescu-Roegen, N., 2008. Opere Complete VI, Cartea a II-a, Energia, resursele naturale și teoria economică. București: România:Expert.

Heesup, H., Jongsik, Y. and Wansoo, K., 2019. Environmental corporate social responsibility and the strategy to boost the airline's image and customer loyalty intentions. Journal of travel\&tourism marketing, 36(3), pp.371-383.

Hopkins, M., 2005. Measurement of corporate social responsability. Int. J. Management and Decision Making, 6(3/4), pp.213-231.

Ivașcu, L. and Ardelean B.O., 2017. Principles of Circular Economy in Romania, Europe and China. In: s.n., 3rd International Conference on Social, Education and Management Engineering (SEME 2017). S.1, n.d. s.l: s.n.

Kim, Y., 2014. Strategic communication of corporate social responsibility (CSR): Effects of stated motives and corporate reputation on stakeholder responses. Public Relations Review, 40, pp.838-840.

Lloyd-Smith, P. and An, H., 2019. Are corporate social responsibility and advertising complements or substitutes in producing firm reputation?. Applied Economics, 51(21), pp.2275-2288.

Lončar, D., Paunković, J., Jovanović, V. and Krstić, V., 2019. Environmental and social responsibility of companies cross EU countries - Panel data analysis. Science of the total environment, 657, pp.287-296.

Márquez, D.I. and Pérez, B.F., 2015. Corporate social responsability : the role of codes of conduct in fostering environmental sustainability in Latin America [online] Available at: <https://hrcak.srce.hr/index.php?show=clanak\&id_clanak_jezik=238169> [Accessed 19 March 2019].

Morato, T., Vaezi, M. and Kumar, A., 2019. Assessment of energy production potential from agricultural residues in Bolivia. Renewable \& Sustainable Eergy Review, [e-journal] 102, pp.14-23. doi: 10.1016/j.rser.2018.11.032. 
Olaru, M., Stoleriu, G. and Șandru, I.M.D. 2011. Social responsibility concerns of SMEs in Romania, from the perspective of the requirements of the EFQM European Excellence Model. Amfiteatru Economic, 13(29), pp.56-71.

Pistol, L., Bucea-Manea-Țoniş, R. and Bucea-Manea-Țoniş, R., 2017. Assumptions on Innovation into a Circular Economy. Journal of Applied Economic Sciences, 5(51), pp.1319-1327.

Sasongko, T., Rifa'i, M. and Sayekti, N., 2019. The Development of the Creative Industries to Create a Competitive Advantage: Studies in Small Business Sector. Journal of Economic Development, Environment and People, 7(3), pp.14-23.

Sawhny, V., 2008. Analyzing Corporate social responsability measureement parameters. Comparing the global reporting initiative to environmental reporting guidelines, government of Japan and the Public Environmental reporting, Australia, Institute for Public Relations [online] Available at <www.instituteforpr.org> [Accessed 18 March 2019].

Săvoiu, G., Manea, C., Iorga-Simăn, V., Enescu, F.M., Čudanov, M., Jaško, O. and Jaško, A. 2011. A corporate model of similitude for SMEs reunion into a corporation, viewed from the angle of physical thought, and its complex economic and social impact. Amfiteatru Economic, 13(29), pp.10-27.

Silva Marins, F.A. and de Araujo, M.V.F., 2016. Green economy and the reverse logistics of waste electrical and electronic equipment. Independent Journal of Management \& Production, [e-journal] 7(1), pp.1-16. dx.doi.org/10.14807/ijmp.v7i1.362.

Staicu, D. and Pop, O., 2018. Mapping the interactions between the stakeholders of the circular economy ecosystem applied to the textile and apparel sector in Romania. Management\&Marketing-Challenges for the knowledge society, 13(4), pp.1190-1209.

Su, L. and Scott, S.R., 2019. Corporate social responsibility (CSR) can be measured by a number of different criteria - Perceived corporate social responsibility's impact on the well-being and supportive green behaviors of hotel employees: The mediating role of the employee-corporate relationship. Tourism management, 72, pp.437-450.

Surugiu, C., Surugiu, M., Mazilescu, R., Cristea, A. and Marginean, I., 2018. Households' Perception of Climate Change Effects in Rural Romania. Annals of Spiru Haret University. Economic Series, [e-journal] 18(3), pp.43-57. https://doi.org/10.26458/1833.

Global Green Growth Institute (GGGI), the Organisation for Economic Co-operation and Development (OECD), the United Nations Environment Programme (UN Environment) and the World Bank, 2019. The European Bioeconomy in 2030. Delivering Sustainable Geowth by addressing the Grand Societal Challenges. [online] Available at <http://www.greengrowthknowledge.org/resource/european-bioeconomy-2030-deliveringsustainable-growth-addressing-grand-societal-challenges> [Accessed 19 March 2019].

Ţoniș-Bucea-Manea, R., 2015a. Enhancing Romanian SMEs Innovation Capacity by Mitigation the Risk Drivers. Applied Mechanics and Materials, 760, pp.757-762.

Țoniș-Bucea-Manea, R., 2015b. SMEs Role in Achieving Sustainable Development. Journal of Economic Development, Environment and People, 4(1), pp.41-50.

Vela, K., 2017. EU Environmental Implementation Review : Highlight, Romania [online] Available <http://ec.europa.eu/environment/eir/pdf/factsheet_ro_en.pdf> [Accessed 14 March 2019]. 